\title{
Mercury mobility in a salt marsh colonised by Halimione portulacoides
}

\author{
M. Válega ${ }^{\mathrm{a}, *}$, A.I. Lillebø ${ }^{\text {a }}$, I. Caçador ${ }^{\mathrm{b}}$, M.E. Pereira ${ }^{\text {a }}$, A.C. Duarte ${ }^{\mathrm{a}}$, M.A. Pardal ${ }^{\mathrm{c}}$ \\ ${ }^{a}$ CESAM and Department of Chemistry, University of Aveiro, 3810-193 Aveiro, Portugal \\ ${ }^{\mathrm{b}}$ IO - Institute of Oceanography, Faculty of Sciences, University of Lisbon, Campo Grande, 1749-016 Lisboa, Portugal \\ ' IMAR - Institute of Marine Research, Department of Zoology, University of Coimbra, 3004-517 Coimbra, Portugal
}

\section{A R T I C L E I N F O}

\section{Article history:}

Received 19 October 2007

Received in revised form 1 April 2008

Accepted 2 April 2008

Available online $\mathrm{xxxx}$

\section{Keywords:}

Halimione portulacoides

Mercury

Salt marsh

Sediments

Ria de Aveiro

\begin{abstract}
A B S T R A C T
The present study intends to increase the knowledge on the mobility of mercury in a salt marsh colonised by Halimione portulacoides. Mercury distribution in the sediment layers and its incorporation into the plant biomass were assessed, as well as the potential export of mercury from the contaminated area to the adjacent environment. Mercury pools in the sediments ranged from 560 to $943 \mathrm{mg} \mathrm{m}^{-2}$ and are largely associated with the solid fraction, with just a small amount being associated with the pore waters. Estimated diffusive fluxes of reactive mercury ranged from 1.3 to $103 \mathrm{ng} \mathrm{m}^{-2} \mathrm{~d}^{-1}$. Despite the above ground biomass values being comparatively higher than below ground biomass values, the mercury pools were much higher in the root system $\left(0.06-0.16 \mathrm{mg} \mathrm{m}^{-2}\right.$ and $29-102 \mathrm{mg} \mathrm{m}^{-2}$, respectively). The annual bioaccumulation of mercury in above ground tissues was estimated in $0.11 \mathrm{mg} \mathrm{m}^{-2} \mathrm{y}^{-1}$, while in below ground biomass the values were higher $\left(72 \mathrm{mg} \mathrm{m}^{-2} \mathrm{y}^{-1}\right)$. The turnover rates of $H$. portulacoides biomass suggest higher mercury mobility within the plant rhizosphere. Taking into account the pools of mercury in above ground biomass, the export of mercury by macro-detritus following the "outwelling hypothesis" is not significant for the mercury balance in the studied ecosystem. The mercury accumulated in the below ground part of the plant is quite mobile, being able to return to the sediment pool throughout the mineralisation process.
\end{abstract}

() 2008 Elsevier Ltd. All rights reserved.

\section{Introduction}

The vital importance of salt marshes is recognised worldwide. Biological productivity, hydrologic flux regulation, biogeochemical cycling of metals and nutrients and habitat for fish and wildlife, are among the several essential ecological functions supported by these ecosystems. (Richardson, 1999; Mitsch and Gosselink, 2000; Caçador et al., 2007; Lillebø et al., 2007; Reboreda and Caçador, 2007). Due to strategic and economical reasons, most of the large cities around the world are located along or nearby estuaries and, as a consequence, and until recently, salt marshes have become subjected to large inputs of contaminants, namely metals derived from urban and industrial effluents which contribute to their vulnerability.

Salt marshes play a significant role in metal recycling in the coastal ecosystems, as they may act as sources, sinks or transformers of chemicals, depending on the wetland type, hydrologic conditions and the time of exposure to the chemical loading (Mitsch and Gosselink, 2000). Some salt marshes may act as sinks for nutrients and contaminants (e.g. Hung and Chmura, 2006; Hwang et al., 2006; Caçador et al., 2007), yet salt marshes can be classified as open systems exporting organic matter (Bouchard and Lefeuvre,

\footnotetext{
* Corresponding author. Tel.: +351 234370 737; fax: +351 234370084 .

E-mail address: mvalega@ua.pt (M. Válega).
}

2000) and nutrients which support estuarine and terrestrial food webs, but they can also export metals (Montague, 1999). The outwelling hypothesis was first introduced by Odum in 1968 and states that marsh-estuarine systems produce more material than can be degraded or stored within the systems, and that the excess material is being exported to the coastal ocean supporting nearcoastal ocean productivity (Dame and Allen, 1996).

Over recent decades, the anthropogenic sources of mercury (e.g. chlor-alkali plants) in aquatic systems have been reduced, due to the high number of restrictive rules and yet mercury is still one of the most hazardous contaminants present in the aquatic environment and it is included in the list of high priority environmental pollutants within the scope of the European Water Framework Directive (WFD). Once released into the aquatic environment, inorganic mercury salts can be converted into more toxic forms, such as organic mercury compounds, particularly methylmercury. The toxicity of organic mercury compounds is higher due to the higher solubility in lipids, which increases the potential for biological uptake and bio-concentration. Methylmercury can be effectively taken up by aquatic organisms with bio-concentration factors of $10^{4}-10^{7}$ (Wiener et al., 2003) and is considered to be the major source of mercury to humans, via the ingestion of fish and seafood (Costley et al., 2000). The organic compounds of mercury in the environment result from methylation processes that are mostly mediated by bacterial activity (biotic processes) (Ullrich et al., 
2001), but can also result from abiotic processes. Physicochemical and biological processes (e.g. erosion, dredging, early-diagenesis, bioturbation) may enhance the presence of organic mercury compounds in the overlying water column affecting the environment on a local/regional scale, particularly in areas highly dependent on fishery activities, endangering the system ecologically, economically and also in terms of human health. The primary way for humans to be exposed to mercury is through the consumption of contaminated fish and shellfish, and therefore knowledge of mercury biogeochemistry in the different compartments of the salt marsh environment is extremely important. As stated before, inputs of mercury into the aquatic systems has been reduced during recent decades although mercury pools in sediments are still a worrying problem due to its potential release into other environmental compartments, such as the overlying water column and biota. The number of studies highlighting the potential role of salt marshes as sinks for several heavy metals, namely mercury (Weis and Weis, 2004; Hung and Chmura, 2006; Kongchum et al., 2006; Válega et al., 2008) has been increasing over recent years; however, most of these studies report only the potential role of vegetation in metal speciation and availability, especially when this is due to root activity (Alloway, 1995; Mendelssohn et al., 1995).

The present study intends to increase the knowledge on the mobility of mercury in a salt marsh colonised by $H$. portulacoides (L.) Aellen (Caryophyllales: Chenopodiaceae), its redistribution in the sediment layers containing plants and its incorporation into below ground biomass. $H$. portulacoides plays an important role in the floristic coverage of the European salt marshes; in fact this species is noted as being one of the most abundant in European salt marshes and one of the most productive species (Bouchard et al., 1998). For these purposes, mercury pools in $H$. portulacoides biomass and in sediments were assessed, as well the potential export of mercury from the contaminated salt marsh to the adjacent areas. Thus, this study provides important data about the dynamic of mercury inside the salt marsh, comprising the below ground and the above ground system.

\section{Material and methods}

\subsection{Study area}

The Ria de Aveiro is a temperate, shallow and well-mixed coastal lagoon located along the Atlantic Ocean (approximately $45 \mathrm{~km}$ long and $10 \mathrm{~km}$ wide) on the northwest coast of Portugal $\left(40^{\circ} 38^{\prime} \mathrm{N} 08^{\circ} 44^{\prime} \mathrm{W}\right)$ (Fig. 1). With an extensive area of wetlands ( $83 \mathrm{~km}^{2}$-high tide and $66 \mathrm{~km}^{2}$-low tide), it is a mesotidal system, where tides are semi-diurnal and propagate from the mouth to the inner lagoon areas. Minimum tidal range is $0.6 \mathrm{~m}$ (neap tides) and the maximum tidal range is about $3.2 \mathrm{~m}$ (spring tides). The Ria de Aveiro is one of the most mercury-contaminated systems in Europe, due to the continuous mercury discharges of a chlor-alkali plant during more than four decades (1950-1994), into an inner bay of $1.5 \mathrm{~km}^{2}$ called Laranjo Bay (Pereira et al., 1998). Laranjo Bay has a salt marsh area where $H$. portulacoides plays an important role in the floristic coverage throughout the year. The Laranjo salt marsh is inundated by tidal action twice a day, which contributes to high detritus exportation to the main system.

\subsection{Sampling}

Samples were collected bi-monthly during a one-year period between April 2003 and April 2004 at the highly contaminated area of Laranjo Bay salt marsh (Fig. 1) during low tide. H. portulacoides biomass (above and below ground biomass), sediments and water samples from intertidal water pools were collected in monotypic stands, uniform in size and in density of stems. Above ground material was collected at ground level in squares of $50 \mathrm{~cm}(n=3)$ and, after cutting the above ground material, three sediment corers of $\varnothing 7 \mathrm{~cm}$ and $15 \mathrm{~cm}$ depth were taken. Below ground biomass of $H$. portulacoides is more abundant in upper layers $(<15 \mathrm{~cm})$, since the effect of root-sediment interactions in the first $15 \mathrm{~cm}$ layers can be more clearly observed. Sediment cores were sliced into $5 \mathrm{~cm}$ layers and one of the cores was preserved un-

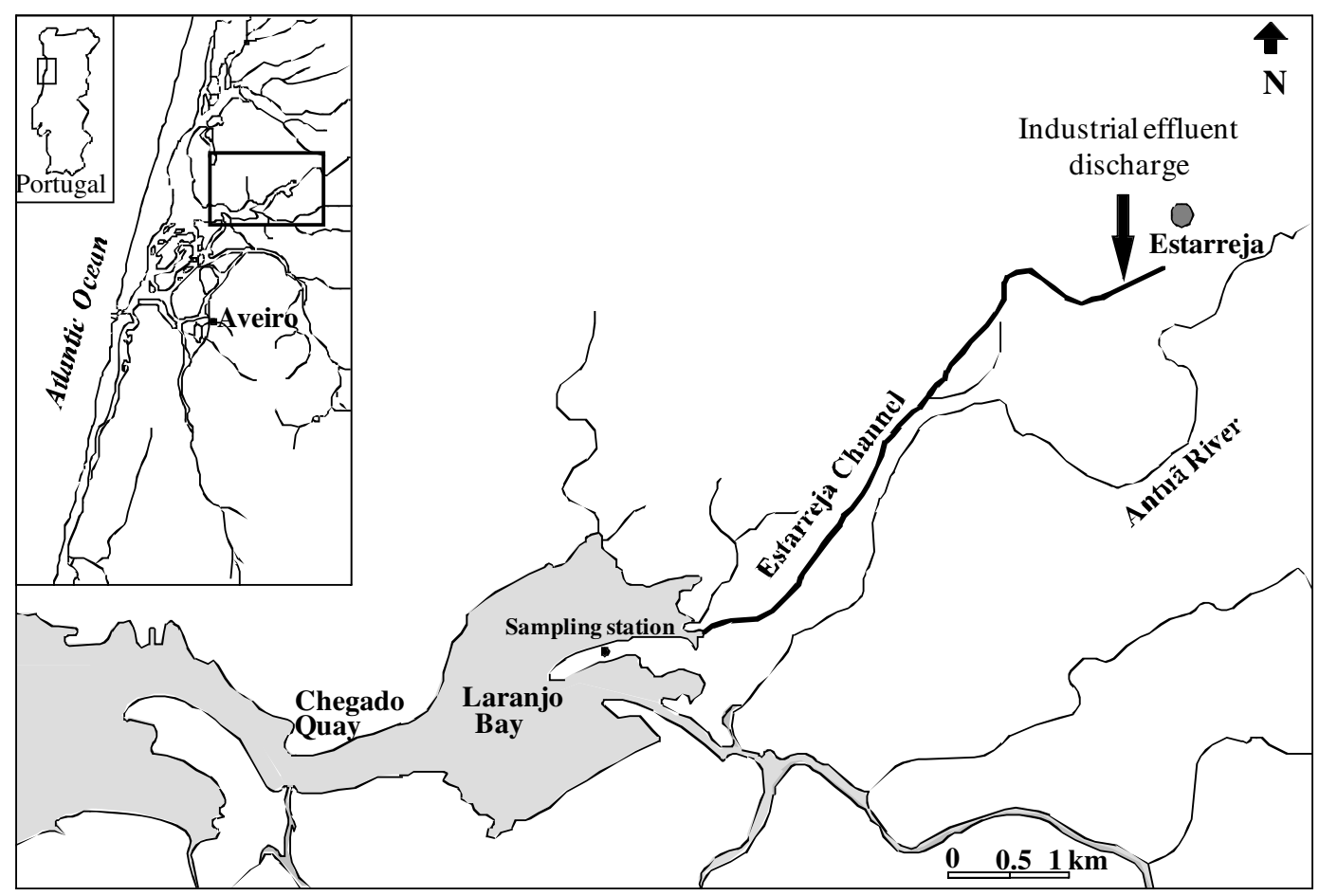

Fig. 1. Location of the Laranjo Bay with the sampling station. 
der $\mathrm{N}_{2}$ environment for pore waters extraction and acid volatile sulphide analysis. Adjacent sediments without vegetation were also collected and sliced at the same depth intervals.

\subsection{In situ measurements}

Previous to sediment segmentation and in situ, redox potential (Eh) and $\mathrm{pH}$ were measured at six replicates in each layer, using calibrated sensors (WTW-pH 330i/set equipped with SenTix ${ }^{\circledR} 41$ and SenTix ${ }^{\circledR}$ ORP). The salinity of the intertidal water pools was also measured (WTW Cond 330i/set equipped with Tetracon ${ }^{\circledR}$ 325 probe).

\subsection{Sample treatment}

Ultra-clean protocols for mercury determinations were used (adapted from Bloom, 1995). All glassware was previously soaked for at least $24 \mathrm{~h}$ in a bath containing 5\% Decon, then in 25\% $\mathrm{HNO}_{3}$ and finally thoroughly rinsed with ultra-pure water (Millipore Milli-Q model 185).

Sediments were homogenised, freeze-dried and sieved ( $1 \mathrm{~mm})$. In the case of the vegetated sediments, roots were separated from the sediments prior to chemical analysis. Below ground biomass was sorted out from the sediments and rinsed with demineralised water until no sediment particles were on the roots and dried, until reaching a constant weight, at $60^{\circ} \mathrm{C}$. Above ground biomass was also carefully washed with demineralised water and dried, until reaching a constant weight, at $60^{\circ} \mathrm{C}$.

Pore waters were extracted from the sediments and always manipulated under $\mathrm{N}_{2}$ atmosphere. The extraction was performed by centrifugation at $3783 \mathrm{~g}$ during $30 \mathrm{~min}$ (B. Braun, model Sigma 4-10). After centrifugation, the pore waters samples were filtered (Millipore $0.45 \mu \mathrm{m}$ ), acidified with $\mathrm{HNO}_{3}$ (mercury-free) to $\mathrm{pH}$ under two and stored in borosilicate acid-clean bottles at $4{ }^{\circ} \mathrm{C}$.

Water samples were transported to the laboratory and processed within a few hours. The samples were filtered (Millipore $0.45 \mu \mathrm{m}$ ), acidified with nitric acid (mercury-free) to $\mathrm{pH}<2$ and stored in borosilicate acid-clean bottles at $4{ }^{\circ} \mathrm{C}$. In order to examine whether there was any possible contamination during the filtration procedures, blank procedures were carried out between the filtration of the water samples through the same filtration unit.

\subsection{Analytical procedures}

Sediment samples were analyzed for water content (wet weight minus dry weight, $120^{\circ} \mathrm{C}$ for $24 \mathrm{~h}$ ), organic matter content as a percentage of loss on ignition (\% LOI) (dry weight minus ash-free dry weight, $500^{\circ} \mathrm{C}$ for $4 \mathrm{~h}$ ), and for fine particles (less than $63 \mu \mathrm{m}$ ) after wet sieving of the dried sample through a $63 \mu \mathrm{m}$ mesh size sieve.

Mercury concentrations in sediments and biomass were determined (at least in triplicate) by atomic absorption spectrometry with thermal decomposition of the sample without prior digestion and collection of the mercury vapour on a gold amalgamator (LECO AMA 254) (Costley et al., 2000). In order to assess the accuracy and precision of the analytical methodology, analysis of certified reference materials were carried out (IAEA 356 and MESS 2 - marine sediments and BCR 060 - trace elements in an aquatic plant) in parallel with samples and procedure blanks. Certified and measured values were in agreement with recoveries between 90106\%, 93-100\% and $90-101 \%$ for IAEA 356, MESS 2 and BCR 60, respectively.

Iron oxides in sediments were determined after extraction (at least triplicate) with $20 \mathrm{ml}$ of a hydroxylammonium chloride solution $\left(0.04 \mathrm{~mol}^{-1}\right.$ in $25 \%$ acetic acid) for $6 \mathrm{~h}$ at room temperature with continuous mechanic agitation. The extracts were separated from the solid residue by centrifugation at $3783 \mathrm{~g}$ for $30 \mathrm{~min}$, and then filtered (Millipore $0.45 \mu \mathrm{m}$ ). Extracted solutions were analyzed by flame atomic absorption spectrometry (Perkin-Elmer, model AAnalyst 100).

Acid volatile sulphides were determined (duplicate) in wet sediments preserved in a $\mathrm{N}_{2}$ atmosphere according to Carapuça et al. (2004), using fast scan linear sweep cathodic stripping voltammetry.

Reactive mercury in pore waters and supernatant waters was determined (duplicate) by cold-vapour atomic fluorescence spectrometry (CV-AFS) (PSA model Merlin 10.023 equipped with a detector PSA model 10.003; limit of detection: $1 \mathrm{ng} \mathrm{l}^{-1}$ ) using $\mathrm{SnCl}_{2}$ $(2 \% \mathrm{~m} / \mathrm{v})$ as the reducing agent. Total dissolved mercury concentrations were also determined (in duplicate) according to the method described by Mucci et al., 1995. This determination is based on the addition of potassium persulphate to the sample and subsequent UV irradiation $(1000 \mathrm{~W})$. The excess of oxidant is reduced with hydroxylamine solution.

\section{Biomass production and mercury pools calculation}

Biomass net primary production (above ground - NPPAbove and below ground - NPPBelow) was estimated according to the differences between the maximum and minimum biomass recorded during the survey period, as described by Caçador et al. (2004). Turnover rate of biomass (above ground and below ground) was estimated according to the ratio between biomass production and the maximum biomass. The macro-detritus annual production was estimated as the product between NPPAbove and the turnover rate of above ground biomass. The mercury pool of the biomass material was calculated by multiplying biomass $\left(\mathrm{g} \mathrm{DW} \mathrm{m}^{-2}\right)$ and mercury concentrations $\left(\mathrm{mg} \mathrm{kg}^{-1}\right)$. Mercury bioaccumulation of $H$. portulacoides was estimated considering the maximum and the minimum of mercury pools in the different tissues of the plant. Mercury turnover was calculated by the ratio between the mercury bioaccumulation and maximum of the mercury pools.

The mercury pool in sediments was calculated per square meter using bulk density $\left(\mathrm{g} \mathrm{cm}^{-3}\right)$ and mercury concentrations in sediments $\left(\mathrm{mg} \mathrm{kg}^{-1}\right)$.

The significance level of the differences between sediment layers and environmental parameters under the surveyed period was assessed with ANOVA test after normality and equal variance tests had been performed.

\section{Results}

\subsection{Sediment characterisation}

Sediment characterisation revealed that the Laranjo Bay sediments are a mixture of sand and mud containing 35-74\% of fine particles (less than $63 \mu \mathrm{m}$ ) (Fig. S1 - supplementary material), with no statistically significant differences between depths. Bulk density was generally lower at vegetated sediments comparative to sediments without vegetation $(0.42 \pm 0.01$ and $0.84 \pm 0.09$, mean \pm st. dev., respectively). Acid volatile sulphides (AVS) of vegetated sediments (Fig. S2 - supplementary material) were below $7.3 \mu \mathrm{mol} \mathrm{g}^{-1}$, ranging between 0.2 and $7.3 \mu \mathrm{mol} \mathrm{g}^{-1}$ (median value $0.83 \mu \mathrm{mol} \mathrm{g}^{-1}$ ) and did not show significant differences between depths or between months $(P>0.05)$; however the highest values were found in the deepest layer $(10-15 \mathrm{~cm})$. The iron oxides concentrations of vegetated sediments (Fig. S3 - supplementary material) were not statistically different, neither between depths nor between months $(P>0.05)$; however the highest values were found in the uppermost layers $(0-5$ and $5-10 \mathrm{~cm})$, where the values ranged between 0.6 and $3.2 \mathrm{mg} \mathrm{g}^{-1}$, while in the deepest layer 
Table 1

Physical and chemical parameters (median values and standard error of the three studied depths) of the Laranjo salt marsh sediments during the surveyed period

\begin{tabular}{llllll}
\hline Parameter & \multicolumn{2}{l}{ Type of sediment } & & \multicolumn{2}{l}{ Non-vegetated } \\
\cline { 2 - 3 } \cline { 5 - 6 } \cline { 5 - 6 } & \multicolumn{2}{l}{ Vegetated } & & & \\
\cline { 2 - 3 } & Median & Standard error & & Median & Standard error \\
\hline pH & 6.2 & 0.1 & & 7.0 & 2.8 \\
Eh $(\mathrm{mV})$ & 102 & 31 & & -165 & -67 \\
Fraction $<63 \mu \mathrm{m}(\%)$ & 51.5 & 12.1 & & 31.2 & 10.4 \\
LOI (\%) & 24.2 & 7.9 & & 9.1 & 3.7 \\
Moisture (\%) & 73.5 & 1.0 & 52.2 & 21.3 \\
\hline
\end{tabular}

$(10-15 \mathrm{~cm})$ the values ranged between 0.3 and $1.4 \mathrm{mg} \mathrm{g}^{-1}$. Salinity values of the intertidal low-water pools ranged between 14 and 37 over the year, with the lowest values being recorded in January and the highest values in July. Physical and chemical parameters (median values of the three studied depths) of the salt marsh sediments are described in Table 1 . Statistically significant differences were only observed in pH (Fig. S4 - supplementary material) and Eh (Fig. S5 - supplementary material) values between depths, and for $\mathrm{pH}$ values between months $(P<0.05)$, the highest $\mathrm{pH}$ values being registered in the winter months. The uppermost layers $(0-$ 5 and $5-10 \mathrm{~cm}$ ) present lower $\mathrm{pH}$ and higher Eh values than the $10-15 \mathrm{~cm}$ layer. Organic matter content (\% LOI) and water content (\% water) were higher in vegetated sediments comparative to nonvegetated sediments $(P<0.05)$. Median values of organic matter content for vegetated sediments were $24.2 \%$ while the non-vegetated sediments presented lower values (9.1\%). The same pattern was observed for the water content of sediments with the highest values in the vegetated sediments (median values $73.5 \%$ ) and the lowest in the non-vegetated sediments (52.2\%).

\section{H. portulacoides biomass net primary production}

Results showed that the $H$. portulacoides below ground annual biomass production was higher than above ground (Fig. 2). The above ground biomass ranged between 978 and $1804 \mathrm{~g} \mathrm{DW} \mathrm{m}^{-2} \mathrm{y}^{-1}$ (Fig. S6 - supplementary material) while below ground biomass (Fig. S7 - supplementary material) for the $15 \mathrm{~cm}$ considered (sum of the three layers $0-5,5-10$ and 10$15 \mathrm{~cm}$ ) ranged between 2781 and $4839 \mathrm{~g} \mathrm{DW} \mathrm{m}^{-2} \mathrm{y}^{-1}$, this being within the range described for other European salt marshes (e.g. Bouchard and Lefeuvre, 2000; Caçador et al., 2004). At the Aveiro system, $H$. portulacoides biomass generally increased from late spring to early summer, and then decreased gradually until late

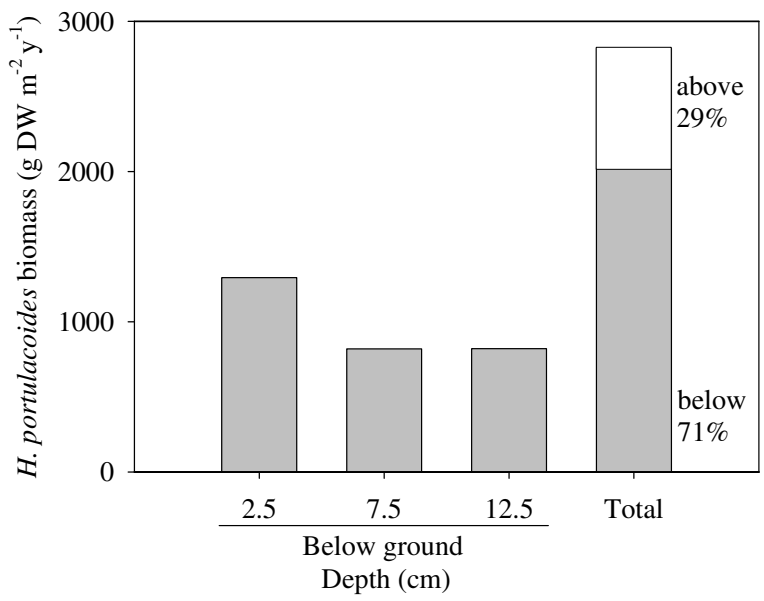

Fig. 2. Annual biomass production of $H$. portulacoides $\left(\mathrm{g} \mathrm{DW} \mathrm{m}^{-2} \mathrm{y}^{-1}\right)$.
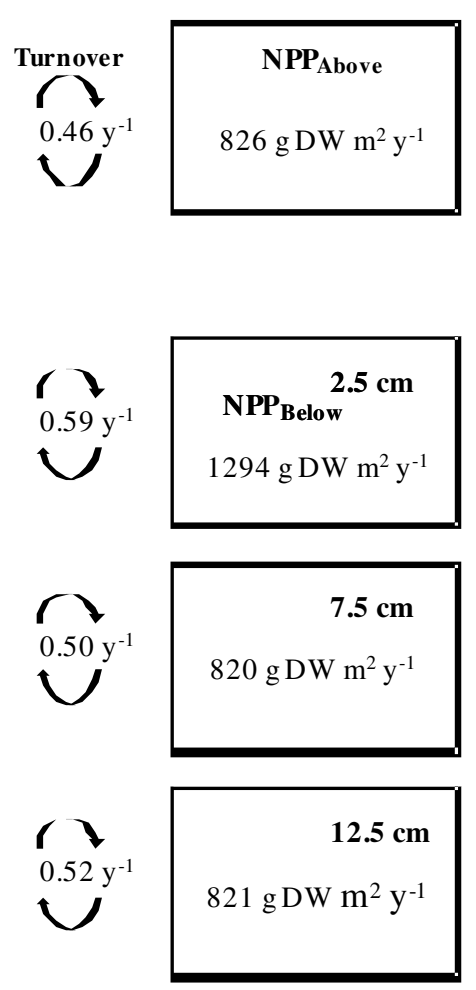

Fig. 3. Schematic representation of $H$. portulacoides net primary production (NPP) and turnover rates for above and below ground biomass.

winter. The highest values of below ground biomass were observed from May to July and the lowest values in autumn. The highest values of above ground biomass were observed in July, which corresponded to the flowering period and November was the month in which the lowest values were registered. Turnover rates for below ground biomass were higher than for above ground biomass. The first layer $(0-5 \mathrm{~cm})$ presented the highest turnover rate $\left(0.59 \mathrm{y}^{-1}\right)$; however, similar rates were observed for deeper layers $\left(0.50 \mathrm{y}^{-1}\right.$ and $0.52 \mathrm{y}^{-1}$ for $5-10$ and $10-15 \mathrm{~cm}$ layers, respectively) while, for above ground biomass, turnover rates of $0.46 \mathrm{y}^{-1}$ were estimated (Fig. 3).

\section{Mercury concentrations in the studied matrices}

Mercury concentrations in above ground biomass tissues (Fig. S8 - supplementary material) were lower and ranged between 0.04 and $0.10 \mathrm{mg} \mathrm{kg}^{-1}$ (average value for stems (young and old stems), leaves and flowers). Higher mercury concentrations $\left(0.06-0.14 \mathrm{mg} \mathrm{kg}^{-1}\right)$ were found in the leaves $(0.03-$ $\left.0.08 \mathrm{mg} \mathrm{kg}^{-1}\right)$ than in the stems $(P<0.05)$ and, in general, higher concentrations were found in April and the lowest in May and July, which correspond to the months with higher biomass values. Statistical tests were performed excluding mercury concentrations in flowers since they only occurred during July and September (although mercury concentrations in flowers presented similar values to the leaves). No statistically significant differences were found in the mercury concentrations of below ground biomass throughout the period of the survey $(P>0.05)$ although significant differences were found between depths $(P<0.05)$. Below ground biomass (Fig. S9 - supplementary material) of the first two layers $(0-5$ and $5-10 \mathrm{~cm})$ presents similar mercury concentrations, ranging between 6.0 and $21.5 \mathrm{mg} \mathrm{kg}^{-1}$, the highest concentrations being found at $10-15 \mathrm{~cm}$ layers (12.4-61.1 $\left.\mathrm{mg} \mathrm{kg}^{-1}\right)$.

Mercury concentrations in the sediments (Fig. S10 - supplementary material) did not show statistically significant differences 
throughout the period of the survey $(P>0.05)$; however, significant differences were observed between layers $(P<0.05)$, the highest concentrations (average \pm st. dev.) being recorded at $10-15 \mathrm{~cm}$ layers $\left(19.1 \pm 5.6 \mathrm{mg} \mathrm{kg}^{-1}\right)$; in fact $0-5$ and $5-10 \mathrm{~cm}$ layers presented similar mercury concentrations $\left(8.2 \pm 1.4 \mathrm{mg} \mathrm{kg}^{-1}\right)$.

Mercury concentrations in non-vegetated sediments collected in Laranjo Bay were generally lower than in sediments with vegetation and ranged between $6.6 \pm 2.2 \mathrm{mg} \mathrm{kg}^{-1}$ and $9.7 \pm 2.4 \mathrm{mg} \mathrm{kg}^{-1}$ for $0-10$ and $10-15 \mathrm{~cm}$ layers, respectively.

Total dissolved and reactive mercury concentrations in pore waters extracted from the sediments did not show statistically significant differences between depths and between months $(P>0.05)$. Reactive mercury concentrations (Fig. 11 - supplementary material) ranged between $1.4 \%$ and $17.8 \%$ of the total dissolved mercury, which varied between 4 and $68 \mathrm{ng} \mathrm{l}^{-1}$. Total mercury concentrations (60-835 $\mathrm{ng} \mathrm{l}^{-1}$ ) in pore waters (Fig. 12 supplementary material) were significantly higher than those observed for reactive mercury. Although dissolved organic mercury concentrations were not measured in this study, pore waters are naturally enriched in organic compounds, especially in vegetated sediments which presents higher organic matter contents due to the roots (Lopes et al., 2006), which can explain the high total mercury concentrations.

Diffusive fluxes across the water-sediment interface were calculated using Fick's first law, considering mercury concentrations of the pore waters in the first centimetres of the sediments and in supernatant water collected in the intertidal low-water pools above the sediment.

Concentrations of reactive mercury in the intertidal pools ranged between 4.4 and $5.6 \mathrm{ng} \mathrm{l}^{-1}$. Estimated diffusive fluxes of reactive mercury varied between 1 and $103 \mathrm{ng} \mathrm{m}^{-2} \mathrm{~d}^{-1}$ with the highest values recorded in July and September.

\section{Mercury pools and mercury bioaccumulation by H. portulacoides}

Mercury pools in above ground biomass ranged between 0.06 and $0.16 \mathrm{mg} \mathrm{m}^{-2}$ while in below ground biomass these values ranged between 29 and $102 \mathrm{mg} \mathrm{m}^{-2}$ (for the three studied depths) the highest values being recorded in the $10-15 \mathrm{~cm}$ depth layer (10$64 \mathrm{mg} \mathrm{m}^{-2}$ ). Mercury pools estimated for the macro-detritus were much lower $\left(0.051 \mathrm{mg} \mathrm{m}^{-2} \mathrm{y}^{-1}\right)$. The annual bioaccumulation of mercury in above ground tissues was estimated in $0.11 \mathrm{mg} \mathrm{m}^{-2} \mathrm{y}^{-1}$, while in below ground biomass, considering the total mercury pools of the three studied depths, it was $72 \mathrm{mg} \mathrm{m}^{-2} \mathrm{y}^{-1}$. The highest values of annual mercury bioaccumulation were found at $10-15 \mathrm{~cm}$ depth $\left(55 \mathrm{mg} \mathrm{m}^{-2} \mathrm{y}^{-1}\right)$, which also corresponded to the highest concentrations of mercury in the sediment (Fig. 4). Mercury pools calculated for the three studied depths ranged between 560 and $943 \mathrm{mg} \mathrm{m}^{-2}$, which is considerably higher when compared to mercury pools found in $H$. portulacoides biomass. Mercury pools of $H$. portulacoides below ground biomass represent only $4-13 \%$ of the mercury pool of the sediments. Mercury pools in sediments without vegetation were higher (1045-1672 $\mathrm{mg} \mathrm{m}^{-2}$ ) due to the differences of the bulk density of the sediments.

\section{Discussion}

According to our results, the presence of vegetation clearly affects sediment parameters, such as Eh, \% LOI, pH, moisture content values and also the mercury concentrations of the sediments (Válega et al., 2008). Vegetated sediments of the Laranjo Bay salt marsh were generally more acidic and Eh values tended to be positive compared to sediments without vegetation. Results suggest

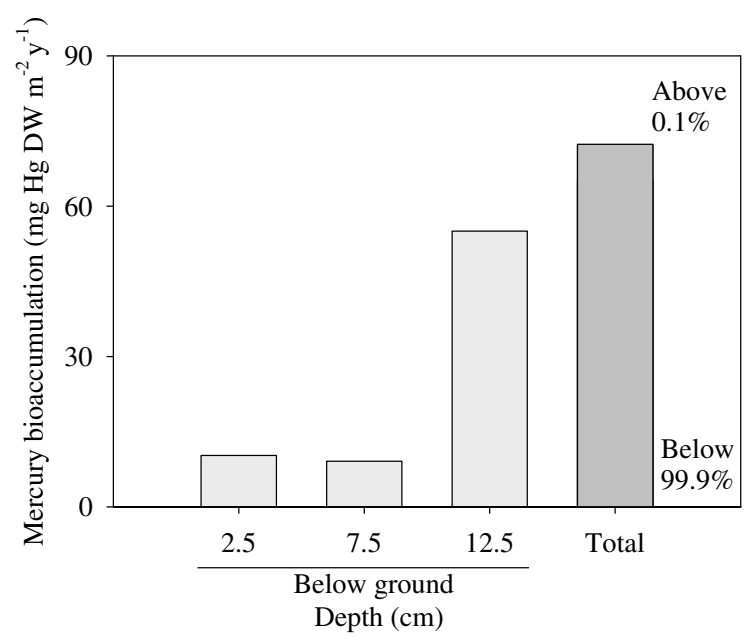

Fig. 4. Annual mercury bioaccumulation by $H$. portulacoides ( $\mathrm{mg} \mathrm{Hg} \mathrm{DW} \mathrm{m}^{-2} \mathrm{y}^{-1}$ ).

that the presence of the root system also seems to contribute to the retention of water in the sediments. Plant roots can interact with the surrounding sediments, pumping oxygen into the root zone through the aerenchyma tissue and acidifying the rhizosphere by the exudation of organic compounds which influence the distribution and availability of trace metals (Alloway, 1995; Mendelssohn et al., 1995; Duarte et al., 2007). In the present study, $H$. portulacoides seems to be active all year, since Eh values showed that in general the rhizosphere is always enriched with oxygen. Eh and $\mathrm{pH}$ have an important role in the bioavailability of metals such as mercury, as partitioning between dissolved and solid fraction is dependent on these parameters. It is stated that anoxic sediments may contain very high concentrations of metals in a reduced state associated with sulphides, reducing their bioavailability when compared to systems with oxidized sediments. The range between -150 and $+200 \mathrm{mV}$ is considered to be the interval where the greatest possible metal mobility exists (Jackson, 1998), which corresponds to the range recorded at the Laranjo Bay salt marsh vegetated by $H$. portulacoides (Table 1 ). The results of $\mathrm{pH}$ and Eh obtained in this study reflect the mobility of mercury in contaminated salt marshes. Marins et al. (1997) have reported that salt marsh plants are able to mobilize deposited mercury through the release of oxygen into the sediments. As plant roots excrete molecular oxygen, the surrounding sediment sulphides are oxidized and iron, manganese and sulphur interact repeatedly in redox reactions. Acid volatile sulphide values of the Laranjo Bay salt marsh sediments were generally low due to the presence of oxygen delivered by the roots. Scavenging of mercury by iron oxides has been reported in a marine environment presenting high contents of iron (Gobeil and Cossa, 1993; Gagnon et al., 1997). As shown by Eh values, sediments at the Laranjo Bay salt marsh are enriched through oxygen being delivered by the roots of $H$. portulacoides, so that iron can precipitate as oxides and contribute to the retention of mercury at the rhizosphere. The results obtained for iron oxides and AVS showed that the different mercury concentrations between depths is not related with the plant activity during the entire year by the delivery of oxygen, and that mercury is not stabilized as sulphides.

Mercury concentrations in sediments and below ground biomass were higher in the deepest layer $(10-15 \mathrm{~cm})$ and in fact this can be explained in relation to the historical mercury contamination of the studied system. The sampling station presents a sedimentation rate of approximately $0.83 \mathrm{~cm} \mathrm{y}^{-1}$, which means that $10-15 \mathrm{~cm}$ layers correspond to periods of mercury discharges from the industry. The chlor-alkali plant started to reduce their discharges in 1994, which explains the lower values of mercury in surface sediment layers. 


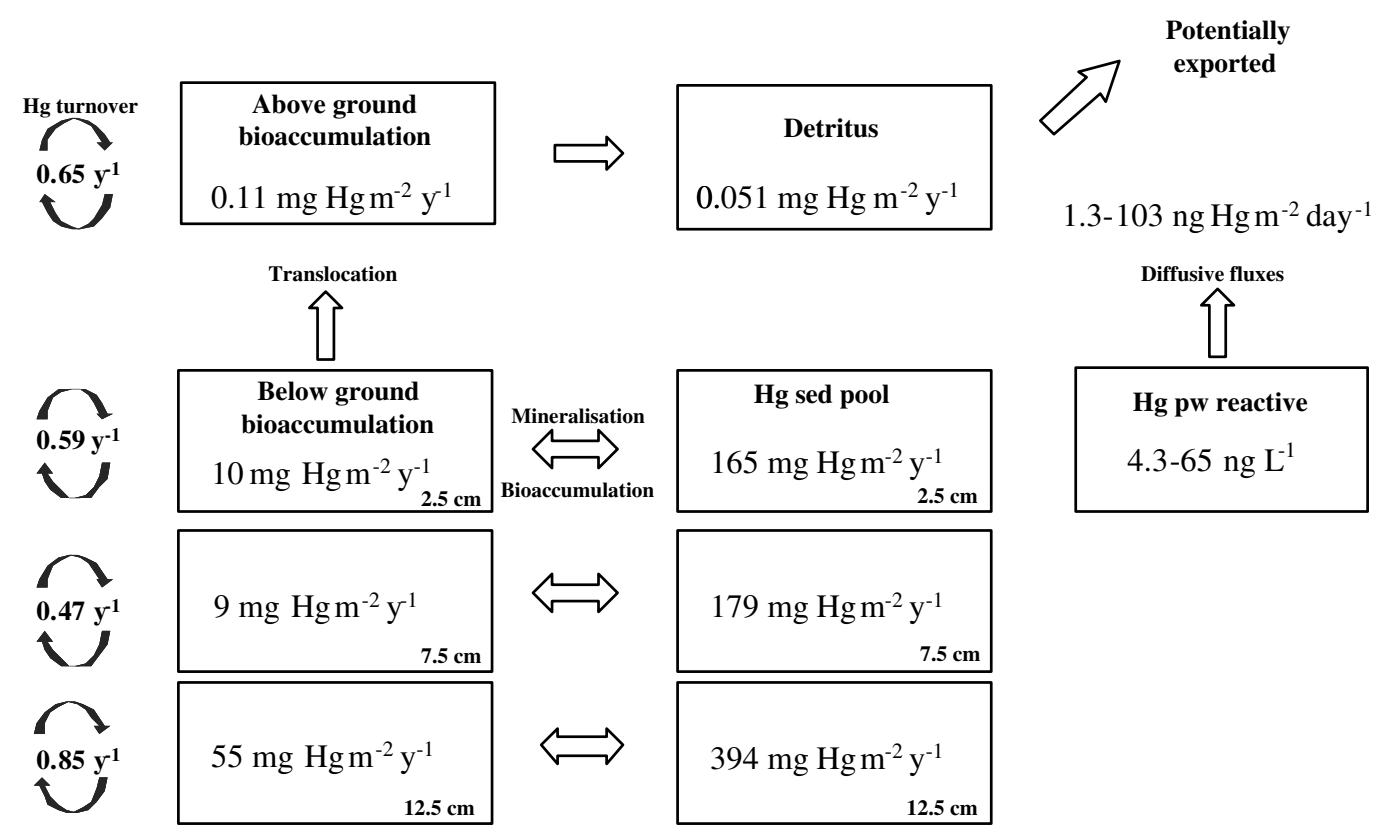

Fig. 5. Schematic representation of mercury mobility in the Laranjo Bay salt marsh colonised by H. portulacoides.

Furthermore, the results obtained also suggest that the pools of mercury in vegetated sediments are largely associated with the solid fraction, with only a small amount associated with the pore waters. A previous work performed in Laranjo Bay by Ramalhosa et al. (2006) in non-vegetated sediments has reported higher values, approximately $5-270 \mathrm{ng} \mathrm{m}^{-2} \mathrm{~d}^{-1}$. The present study suggests that the contribution of vegetated sediments to reactive mercury concentrations in the water column is not significant, which is particularly relevant since reactive mercury is pointed out as a suitable measure of the metal substrate available for methylation, elemental mercury formations and other conversion processes of mercury within the aquatic environment (Mason, 1993).

Pools of mercury bioaccumulated by $H$. portulacoides was much lower at above ground biomass (0.1\%) (Fig. 4), suggesting that mercury mobility is mainly between sediments and roots and only a very small fraction is translocated to the above ground parts of the plant. Mercury budgets clearly show that roots are the main organ for mercury accumulation. Below ground material presented higher concentrations of mercury by $174-545$-fold than above ground tissues and by $0.8-8.4$-fold than sediments. According to a recent study performed in two Portuguese salt marshes of the Tagus estuary (approximately $250 \mathrm{~km}$ south from Ria de Aveiro) (Pereira et al., 2007), the decomposition of the below ground biomass of $H$. portulacoides corresponded closely to $42-46 \%$ of mass lost (dry weigh) in the first months. This suggests that the pool of mercury bioaccumulated in the below ground part of the plant is quite mobile, being able to return to the sediment pool throughout the mineralisation process and/or contribute to reactive mercury concentrations in pore waters.

Macro-detritus production of above ground biomass of $H$. portulacoides was estimated to be $378 \mathrm{~g} \mathrm{~m}^{-2} \mathrm{y}^{-1}$, which means that about $46 \%$ of the biomass can be rapidly transformed into necromass. The detrital material can be exported from the contaminated inner bay, the Laranjo Bay, or redistributed within the salt marsh. According to the studies of Bouchard and Lefeuvre (2000), a significant fraction of the detritus is usually redistributed inside the salt marsh. The potential of the system to export macro-detritus (either to coastal waters or to other areas of the system) appears to be strongly influenced by its proximity to the creek network and the
Laranjo Bay salt marsh has a high number of creeks in which water flows. For each tidal cycle at Laranjo Bay, it has been estimated that approximately $1.5 \times 10^{6} \mathrm{~m}^{3}$ of water (mean value) flows out of the bay during the ebb tide and about $0.5 \times 10^{6} \mathrm{~m}^{3}$ remains in the main channel between Chegado Quay and Bico Quay (Fig. 1), which flows in the incoming tide. The volume of water that flows out from Laranjo Bay during neap tide was estimated as being approximately $3 \%$ of the total volume of water that is changed in each tidal cycle between the entire system of the Ria de Aveiro lagoon and the Atlantic Ocean. The potential of this inner bay to export macrodetritus appears to confer some mobility to the pool of mercury bioaccumulated in the above ground part of $H$. portulacoides (the above ground corresponded to $29 \%$ of the plant total biomass). The mercury pool in this macro-detritus was comparatively low (the annual mercury pool of above ground biomass represented $0.1 \%$ of the total pool of mercury in the plant), yet it constitutes a source of mercury to be exported from the contaminated inner bay, the Laranjo Bay into the Ria system.

\section{Conclusions}

The turnover rates for below ground biomass were higher than those observed for above ground biomass, corresponding to higher mercury mobility within $H$. portulacoides rhizosphere. Temporal differences between the mercury pools correspond to the mercury that can be mobilized within the salt marsh, namely being bioaccumulated by the plant or being potentially exported from the contaminated inner bay. Fig. 5 shows a schematic representation of the mobility of mercury in the Laranjo Bay salt marsh colonised by $H$. portulacoides. Taking into account the pool of mercury in above ground biomass of $H$. portulacoides, the export of mercury by macro-detritus following the "outwelling hypothesis" is not significant for the mercury balance in the studied system. The bioaccumulated mercury in the below ground part of the plant is quite mobile, being able to return to the sediment pool throughout the mineralisation process and/or contribute to reactive mercury concentrations in pore waters. This case study may be seen as a starting point to address mercury mobility within salt marshes, and help to identify critical environmental information gaps. 


\section{Acknowledgement}

This research was supported by the Portuguese Science and Technology Foundation (FCT) through a PhD grant (SFRH/BD/ 18682/2004) funding M. Válega.

\section{Appendix A. Supplementary material}

Supplementary data associated with this article can be found, in the online version, at doi:10.1016/j.chemosphere.2008.04.007.

\section{References}

Alloway, B.J., 1995. Soil processes and the behaviour of heavy metals. In: Alloway, B.J. (Ed.), Heavy Metals in Soils. Blackie Academic Publications, UK.

Bloom, N.S., 1995. Mercury as a case-study of ultraclean sample handling and storage in aquatic trace metal research. Environ. Lab. (March/April 20).

Bouchard, V., Creach, V., Lefeuvre, J.C., Bertru, G., Mariotti, A., 1998. Fate of plant detritus in a European salt marsh dominated by Atriplex portulacoides (L.). Aellen. Hydrobiol. 373/374, 75-87.

Bouchard, V., Lefeuvre, J.C., 2000. Primary production and macro-detritus dynamics in a European salt marsh: carbon and nitrogen budgets. Aquat. Bot. 67, 23-42.

Caçador, I., Costa, A.L., Vale, C., 2004. Carbon storage in Tagus salt marsh sediments. Water Air Soil Poll. 4, 701-714.

Caçador, I., Costa, A.L., Vale, C., 2007. Nitrogen sequestration capacity of two salt marshes from the Tagus estuary. Hydrobiologia 587, 137-145.

Carapuça, H.M., Válega, M., Pereira, E., Duarte, A.C., 2004. Monitoring acid-volatile sulphide by a fast scan voltammetric method: application to mercury contamination studies in salt marsh sediments. Anal. Chim. Acta 524, 127-131.

Costley, C., Mossop, K., Dean, J., Garden, L., Marshall, J., Carroll, J., 2000. Determination of mercury in environmental and biological samples using pyrolysis atomic absorption spectrometry with gold. Anal. Chim. Acta 405, 179-183.

Dame, R.F., Allen, D.M., 1996. Between estuaries and the sea. J. Exp. Mar. Biol. Ecol. 200, 169-185.

Duarte, B., Delgado, M., Caçador, I., 2007. The role of citric acid in cadmium and nickel uptake and translocation, in Halimione portulacoides. Chemosphere 69, 836-840.

Gagnon, C., Pelletier, E., Mucci, A., 1997. Behaviour of anthropogenic mercury in coastal marine sediments. Mar. Chem. 59, 159-176.

Gobeil, C., Cossa, D., 1993. Mercury in sediments and pore water in the Laurentian Though. Can. J. Fish. Aquat. Sci. 50, 1794-1800.

Hwang, H.M., Green, P.G., Higashi, R.M., Young, T.M., 2006. Tidal salt marsh sediment in California, USA. Part 2: occurrence and anthropogenic input of trace metals. Chemosphere 64, 1899-1909.

Hung, G.A., Chmura, G.L., 2006. Mercury accumulation in surface sediments of salt marshes of the Bay of Fundy. Environ. Pollut. 142, 418-431.

Jackson, L.J., 1998. Paradigms of metal accumulation in rooted aquatic vascular plants. Sci. Total Environ. 219, 223-331.
Kongchum, M., Devai, I., DeLaune, R.D., Jugsujinda, A., 2006. Total mercury and methylmercury in freshwater and salt marsh soils of the Mississippi river deltaic plain. Chemosphere 63, 1300-1303.

Lillebø, A.I., Flindt, M.R., Pardal, M.A., Cardoso, P., Ferreira, S., Marques, J.C., 2007. The faunal role on the degradation of the common intertidal salt-marsh plant Scirpus maritimus. Hydrobiologia 579, 369-378.

Lopes, C.B., Abreu, S., Válega, M., Duarte, R.M.B.O., Pereira, M.E., Duarte, A.C., 2006. The assembling and application of an automated segmented flow analyzer for the determination of dissolved organic carbon based on UV-persulphate oxidation. Anal. Lett. 39, 1979-1992.

Marins, R.V., Lacerda, L.D., Gonçalves, G.O., Paiva, E.C., 1997. Effect of root metabolism on the post-depositional mobilization of mercury in salt marsh soils. Bull. Environ. Contam. Toxicol. 58, 733-738.

Mason, R.P., 1993. Mercury biogeochemical cycling in a stratified estuary. Limnol. Oceanogr. 38, 1227-1241.

Mendelssohn, I., Kleiss, B., Wakeley, J., 1995. Factors controlling the formation of oxidized root channels in wetland plants: a review and annotated bibliography. Wetlands $15,37-47$.

Mitsch, W.J., Gosselink, J.G., 2000. Wetlands, third ed. John Wiley \& Sons, Inc., USA. Montague, C.L., 1999. Encyclopedia of Environmental Science. Kluwer Academic Publishers.

Mucci, A., Lucotte, M., Montgomery, S., Plourde, Y., Pichet, P., VanTra, H., 1995 Mercury remobilization from flooded soils in a hydroelectric reservoir of northern Quebec, La Grande-2: results of a soil resuspension experiment. Can. J. Fish. Aquat. Sci. 52, 2502-2517.

Pereira, M.E., Duarte, A.C., Millward, G.E., Vale, C., Abreu, S.N., 1998. Tidal export of particulate mercury from the most contaminated area of Aveiro's Lagoon, Portugal. Sci. Total Environ. 213, 157-163.

Pereira, P., Caçador, I., Vale, C., Caetano, M., Costa, A.L., 2007. Decomposition of belowground litter and metal dynamics in salt marshes (Tagus estuary, Portugal). Sci. Total Environ. 380, 93-101.

Ramalhosa, E., Segade, S.R., Pereira, E., Vale, C., Duarte, A., 2006. Mercury cycling between the water column and surface sediments in a contaminated area. Water Res. 40, 2893-2900.

Reboreda, R., Caçador, I., 2007. Copper, zinc and lead speciation in salt marsh sediments colonised by Halimione portulacoides and Spartina maritima. Chemosphere 69, 1655-1661.

Richardson, C.J., 1999. Plenary session presentation: ecological functions of wetlands in the landscape. In: Lewis et al. (Eds.), Ecotoxicology and Risk Assessment for Wetlands. SETAC Press, USA, pp. 9-25.

Ullrich, S.M., Tanton, T.W., Abdrashitova, S.A., 2001. Mercury in the aquatic environment: a review of factors affecting methylation. Crit. Rev. Environ. Sci. Technol. 31, 241-293.

Válega, M., Lillebø, A.I., Pereira, M.E., Duarte, A.C., Pardal, M.A., 2008. Long-term effects of mercury in a salt marsh: hysteresis in the distribution of vegetation following recovery from contamination. Chemosphere 71, 765-772.

Weis, J.S., Weis, P., 2004. Metal uptake, transport and release by wetland plants: implication for phytoremediation and restoration. Environ. Int. 30, 685-700.

Wiener, J.G., Krabbenhoft, D.P., Heinza, G.H., Scheuhammer, A.M., 2003. Ecotoxicology of mercury. In: Hoffman, D.J. et al. (Eds.), Handbook of Ecotoxicology. CRC Press, Boca Raton, Florida, pp. 409-463. 